\title{
Factors associated with fear of childbirth: It's effect on women's preference for elective cesarean section
}

\author{
Samah Nasser Abd El-Aziz * Suzan El-Said Mansour, Nahed Fikry Hassan \\ Faculty of Nursing, Mansoura University, Mansoura, Egypt
}

Received: June 27, 2016

Accepted: July 31, 2016

Online Published: September 20, 2016

DOI: $10.5430 /$ jnep.v7n1p133

URL: http://dx.doi.org/10.5430/jnep.v7n1p133

\begin{abstract}
Background and objective: Childbirth fear is a major problem for women, as it results in avoidance of maternity, women \& fetal stress and raise in women requests for cesarean delivery. The aim of this study is to investigate factors associated with fear of childbirth (FOC), and its effect on women's preference for elective cesarean section (CS).

Methods: Design: Cross sectional descriptive design. Setting: Study conducted at five obstetrical and gynecological private clinics in El-Mahalla El-Kobra city. Subjects: A purposive sample consisted of 205 pregnant women selected according to the inclusion and exclusion criteria. Tools: Three tools were used for data collection (Structured Interview Questionnaire, Melender (2002) Questionnaire to measure childbirth fear associated factors and Childbirth Attitudes Questionnaire).

Results: Revealed that $47.8 \%$ of pregnant women preferred elective CS. Fear of vaginal birth, safer mode for the baby, no influence on postpartum sexual life and pain associated with delivery were the most reasons for CS preference. Childbirth factor was the highest factor associated with FOC with mean \pm SD $12.439 \pm 3.949$. Fear of pain, episiotomy and lacerations were the highest sub factors representative for childbirth factor $(89.3 \%, 83.9 \%$, and $82.4 \%$ respectively). The highest cause of FOC was negative mood with mean \pm SD $13.302 \pm 3.500 .50 .0 \%$ of pregnant women with high FOC preferred CS.

Conclusions and recommendations: Childbirth factor was the highest factor associated with FOC. Fear of pain, episiotomy and lacerations were the highest sub factors representative for childbirth factor associated with FOC. Pregnant women with high fear of childbirth preferred cesarean section. Recommendations: Undertaking information, education and communication programs to increase awareness of the women, husbands, health providers and society about childbirth fear and its effect on cesarean section preference in order to decrease elective cesarean section rate.
\end{abstract}

Key Words: Fear of childbirth, Preference, Elective cesarean section

\section{INTRODUCTION}

Women all around the world give birth every day in different circumstances and within different cultures. While childbirth is commonly regarded as a natural process, women expect to obtain a definite type of care. Women's expectations and ultimately their overall satisfaction are greatly relied on their conceptualization of what comprise normal delivery and the huge amount of socio-economic and behavioral factors re- lated to their birthing experience. ${ }^{[1]}$

The lives of Egyptian women are often obligated by rules of law, religion and a culture that appreciates motherhood greatly. In Egypt women view childbirth as a difficult experience, full of fear and alienation as well as traditional birth attendants considered childbirth a stressful situation where the woman has no chance to be relaxed. ${ }^{[2]}$

\footnotetext{
* Correspondence: Samah Nasser Abd El-Aziz; Email: dr_samah1987@yahoo.com; Address: Demonstrator of Woman Health and Midwifery Nursing, Faculty of Nursing, Mansoura University, Mansoura, Egypt.
} 
During the 19th and 20th centuries, a change has occurred in the rituals of childbirth, particularly with rules regarding the care provider (from midwives to obstetricians) and the place (from the home to the hospital). Women's decision to come to the hospital may be produced by a culture of fear, imposing a sense of risk on pregnancy and delivery to encourage births to occur in hospitals, where obstetricians have the final word. ${ }^{[1]}$

Childbirth connected fear is identified as a condition that seems chiefly before giving birth, covers a range of symptoms from worries to sever fear impacting daily life throughout pregnancy towards the approaching birth, and is used as diagnosing and thereby as a reason for cesarean birth. Women might experience a variety of fears in relation to pregnancy and giving birth. ${ }^{[3]}$

Various reasons for fear of childbirth have been reported such as fear of pain, fear of losing control, fear of rupturing, fear of operative delivery and fear of having an impaired or stillborn infant. ${ }^{[4]}$ Several factors have been related to raised prevalence of fear of giving birth, include young maternal age, nulliparity, preexisting psychological issues, inadequate social support and a history of abuse or difficult obstetric procedures. ${ }^{[5,6]}$

Childbirth fear has implications for women's health as it is a primary psychological issue that contributes to women's requests for interventions and disruption of physiological labor. Antenatal fears might expect pain and distress throughout labor and raise the risk of severe emotional instability postnatally. ${ }^{[7]}$

Fear of childbirth and women requested cesarean deliveries are strongly connected. Women who fear parturition are more possible to request a cesarean and are also more probably to actually have a planned cesarean, ${ }^{[8,9]}$ in spite of the fact that cesareans are associated with disadvantages for the woman and baby. ${ }^{[10,11]}$

Cesarean delivery on maternal request has been identified as a crucial factor for raising cesarean delivery rate. ${ }^{[12]} \mathrm{Ce}-$ sarean section (CS) on woman request is defined as a cesarean performed for a single gestation on woman request without medical or obstetrical reasons. This can be a modern concept involving variety of moral, emotional and legal issues. ${ }^{[13]}$

Worldwide cesarean delivery rates have increased remarkably over the last twenty years. ${ }^{[14]}$ The increase in cesarean section rates is problematic for variety of causes. Cesarean section has been associated with raised women mortality and unhealthy neonatal outcomes, amplified physical and emotional women morbidity and higher costs to health care systems. ${ }^{[15]}$

In Egypt, social norms are passed-on from one generation to another, therefore such norms are important factors on the preferences of delivery by women. Expectant mothers acquire information related to delivery, especially from family members, friends, the environment in which they live, and the process may be impacted by their experiences, recommendations and social authorization.

Preferences for CS are usually connected to factors like anxiety, birth fear, prior C-section, prior negative birth experiences, maternal age, changing in the perception of surgical risks, phobia of labor pain, negative attitude toward vaginal delivery, concerns regarding the baby's well-being, prevention of urogenital lacerations and alteration in sexual relations. ${ }^{[16-19]}$

Childbirth fear has consequences. In addition to the sufferance and therefore the stress in everyday life, fear of childbirth usually implies asking for elective cesarean, regardless of the known risks of cesarean operation. Consequently, to decrease fear and the morbidity both of women and babies due to obstetric complications and unneeded cesareans, Therefore, it is of huge importance to investigate factors associated with fear of childbirth and its effect on women's preference for elective cesarean section.

\subsection{Significance of the study}

This study responds to the globally rising rate of cesarean delivery and specifically to the very high rate of elective cesarean delivery among Egyptian women as evidences recommended that such elective cesareans cause possible health risks for women and infants. In Egypt, the overall rate of delivery by CS has raised dramatically from $27.6 \%$ in 2010 to $52 \%$ in 2014 and $65 \%$ in Gharbia in 2014. These rates are more than other rates quoted from diverse parts of the world, both in the developed and developing countries. ${ }^{[20,21]}$

Fear of childbirth has received great attention in Scandinavian countries, ${ }^{[4,22,23]}$ the UK, ${ }^{[24]}$ Australia, ${ }^{[25,26]} \mathrm{Canada}^{[27]}$ and Turkey ${ }^{[28]}$ but not in Egypt. Yet, few studies have examined the mode of birth among women with fear of childbirth.

The prevalence of fear related to childbirth is around $20 \%$ with about $6 \%-10 \%$ of women experiencing high fear of delivery which is dysfunctional or disabling. ${ }^{[29]}$ An additional $13 \%$ of non-pregnant women are fearful enough of parturition to delay or evade maternity. ${ }^{[30]}$ If pregnant woman thinks that she cannot control delivery, the consequential fear and anxiety makes her prefer CS in the absence of medical reasons. ${ }^{[31]}$ Therefore, this study aimed to investigate factors associated with FOC and women's preference for elective CS. 


\subsection{Aim of the study}

This study aimed to investigate the factors associated with FOC: its effect on women's preference for elective cesarean section.

\subsection{Research questions}

(1) What are the factors associated with FOC?

(2) What is the effect of FOC on women's preference for elective CS?

\section{SUBJECTS AND METHOD}

\subsection{Design}

Cross sectional descriptive design was utilized in this study.

\subsection{Setting}

The current study conducted at five obstetrical and gynecological private clinics in El-Mahalla El-Kobra city.

\subsection{Sample type}

A purposive sample consisted of 205 pregnant women selected according to the inclusion and exclusion criteria.

\subsection{Inclusion criteria}

(1) Age is more than 18 and less than 35 years.

(2) Nulliparous women.

(3) Gestational age 30-40 weeks.

(4) Free from any medical or obstetrical complications.

(5) Accept to participate in the study.

\subsection{Exclusion criteria}

(1) Multiparous women.

(2) Have medical or obstetrical complications.

\subsection{Sample size}

The study included 205 pregnant women. Sample size was calculated according to the following formula: ${ }^{[17]}[(\mathrm{Z1}-$ $\left.\alpha / 2)^{2} \mathrm{p}(1-\mathrm{p})\right] / \mathrm{d}^{2}$; Where Z1- $\alpha / 2$ (the standard normal variate, at $5 \%$ type 1 error $(p<.05)$ equal $1.96, \mathrm{p}$ (the expected proportion in population based on prior studies or pilot study) equal $0.158, \mathrm{~d}$ (the absolute error or precision) equal 0.05 .

\subsection{Tools of data collection}

To achieve the aim of this study, three tools were used for data collection. Tools were revised by three experts and their comments have been considered.

Tool I: Structured Interview Questionnaire was designed by the researchers after reviewing the national and international related literatures. It consisted of $17 \mathrm{MCQ}$. It entailed three parts as follow:

Published by Sciedu Press
Part I: It was designed to assess the general characteristics of the pregnant women and consisted of 10 questions (e.g., age, educational level, occupation, residence and family income). Part II: It was designed to assess obstetric data and consisted of three questions (e.g., number of pregnancy, number of miscarriage, gestational age). Part III: It was designed to assess delivery mode preference and reasons for preference. It consisted of four questions (e.g., preferred birth type for the current pregnancy, reasons for preference and history of cesarean among relatives).

Tool II: Melender (2002) Questionnaire adopted from Melender (2002) to measure factors associated with childbirth fear. It consisted of 2 domains to measure the following:

(1) Factors of fear consisted of five factors including (childbirth, child's and mother's wellbeing, health care staff, family life \&cesarean section).

(2) Causes of fear included five causes including (negative mood, negative stories, alarming information, disease and child-related problems).

Every statement was answered with a 4-point scale $(1=$ agree, 2 = agree to some extent, $3=$ disagree to some extent, $4=$ don't agree). Sum scores ranged from 21 to 84, with higher scores reflecting a lower degree of FOC.

Tool III: Childbirth Attitudes Questionnaire (CAQ) adopted from Lowe (2000) to assess level of childbirth fear. It consisted of a 16-item questionnaire such as (I am really afraid of giving birth) \& (I have fear of painful labor contractions).Every item was answered with a 4-point scale $(1=$ no fear, $2=$ mild fear, $3=$ moderate fear, $4=$ high fear). Sum scores ranged from 16 to 64 , with higher scores reflecting a higher level of FOC. A score equal to or lower than 32 is considered low fear, a score between 33 and 48 equates to moderate fear and a score higher than 48 represents a high level of fear.

\subsection{Development of study tools validity}

Tools used in the study were developed by the researchers after reviewing of the current national and international related literatures using books, articles and scientific journals. This helped to be familiar with the problem, and guided in the process of tools' designing. Tools were reviewed by three jury from experts in maternity nursing field tested the content validity. According to expert's suggestions the tools were modified.

\subsection{Reliability}

Reliability of tools was tested for pregnant women during pilot study by using Cronbach's $\alpha$ (alpha). Reliability for tool II: Melender (2002) Questionnaire was ranged from 0.70 to 
0.91 and tool III: Childbirth Attitudes Questionnaire (CAQ) had an internal consistency reliability estimate of 0.83 and hence the questionnaire was found to be highly reliable. ${ }^{[32,33]}$

\subsection{Pilot Study}

Pilot study phase was carried out for one month (October 2015) at five obstetrical and gynecologic private clinics in El-Mahalla El-Kobra city on $10 \%$ of the sample size (20 pregnant women) to test the applicability \& relevance of the research tools \& the clarity of the designed questionnaire and the required modifications were made. The pilot sample was excluded from the study.

\subsection{Ethical Considerations}

Ethical approval was attained from research ethics committee of the Nursing Faculty, Mansoura University. An ethical approval was taken from the physicians of obstetrical and gynecological private clinics in El-Mahalla El-Kobra city to obtain the official permission to conduct the study after explaining the objective of the study. Written informed consents were attained from every pregnant women recruited in the study \& after clarification of the nature objective of the study. Women were reassured about the Anonymity, privacy, safety \& confidentiality of the collected information throughout the whole study, and were informed about their rights to refuse participations or leave the study at any time.

\subsection{Data collection}

The actual field work of the research occurred for six months period beginning on October 2015 and finished on March 2016 to gather the data required for assessment of childbirth fear. Data were gathered using a sample from five obstetrical and gynecologic private clinics in El-Mahalla El-Kobra city three days per week from 5 p.m. to 10 p.m. Firstly, the researchers introduced themselves to physicians, took consent of them to conduct study in their clinics after clarification of the aim of study. Then the researchers reviewed follow-up cards of pregnant women who are attending five obstetrical and gynecologic private clinics to select participants according to inclusion and exclusion criteria. The researchers knew their next follow-up appointment and went to the mentioned settings at that date. The researchers introduced themselves to pregnant women, took written consent of them to be included within the study after clarification of study aim. During the interview, the researchers read every point of the data collection sheet $\&$ clarified its meaning to the woman. Women were permitted to ask for any interpretation or explanation (it took about 20-25 minutes per woman). The researchers began with structured interview questionnaire to collect general characteristics, obstetric data and determine the preferred delivery mode for the current pregnancy and its reasons then recorded women's answers in the data collection sheet. Then the researchers used Melender questionnaire to measure factors associated with childbirth fear and ended with CAQ to assess level of childbirth fear and recorded women's answers in the data collection sheet. The collected data are coded then stored and the results were analyzed.

\subsection{Statistical analysis}

The data were collected by questionnaires \& structured tools, coded, computed and statistically analyzed using SPSS (statistical package of social sciences) version 16. The qualitative data were presented in tables as frequency and percentage while quantitative data were presented as mean \pm SD. Comparing the qualitative variables was done using Chi square $\left(\chi^{2}\right)$, while comparing quantitative variables in two groups was done using student $t$ test, and more than two groups using one way anova test ( $F$ test). The correlation of two quantitative variables was done using Pearson's correlation coefficient. The difference was considered significant if $p \leq .05$.

\section{RESULTS}

Table 1 shows the frequency distribution of pregnant women according to their general characteristics. It showed that the mean age of pregnant women was $23.2 \pm 3.5$ and the mean age at marriage of them was $21.5 \pm 3.6$. Concerning educational level, the results showed that $52.2 \%$ of pregnant women and $55.1 \%$ of their husbands respectively were secondary educated. The majority of women were housewives $(62.0 \%)$ and their husbands work was Full-time job (67.3\%). Meanwhile, $66.8 \%$ of pregnant women had personal house, $68.3 \%$ of pregnant women came from rural origin. In addition, $63.9 \%$ of them were reported adequate income.

Table 2 describes the frequency distribution of obstetric history among pregnant women. It showed that $84.9 \%$ of pregnant women didn't attend antenatal classes. Regarding number of gravida and miscarriage, the results showed that $76.1 \%$ of pregnant women were primi gravida and didn't have any miscarriage. $56.1 \%$ of women were pregnant between 30-34 weeks. In addition, $67.4 \%$ of pregnant women had relatives who have had cesarean delivery; meanwhile $67.3 \%$ of pregnant women had 1-2 relatives who have had cesarean delivery.

Figure 1 shows the frequency distribution of delivery mode preference among pregnant women. The results reported that $52.2 \%$ of pregnant women preferred vaginal delivery compared to $47.8 \%$ of pregnant women preferred elective cesarean section. 
Table 1. Frequency distribution of pregnant women according to their general characteristics

\begin{tabular}{|c|c|c|}
\hline Characteristics & No. $(n=205)$ & $\%$ \\
\hline \multicolumn{3}{|l|}{ Age (yrs.) } \\
\hline $18-23$ & 127 & \multirow{2}{*}{62.0} \\
\hline $24-29$ & 62 & \\
\hline $30-35$ & 16 & \multirow{2}{*}{$\begin{array}{l}30.2 \\
7.8\end{array}$} \\
\hline Mean \pm SD & $23.2 \pm 3.5$ & \\
\hline \multicolumn{3}{|l|}{ Age at marriage(yrs.) } \\
\hline $18-23$ & 162 & \multirow{2}{*}{79.0} \\
\hline $24-29$ & 36 & \\
\hline $30-35$ & 7 & 17.0 \\
\hline Mean \pm SD & $21.5 \pm 3.6$ & 3.4 \\
\hline \multicolumn{3}{|l|}{ Educational level } \\
\hline Basic and less & 30 & 14.6 \\
\hline Secondary & 107 & 52.2 \\
\hline University & 68 & 33.2 \\
\hline \multicolumn{3}{|l|}{ Occupation } \\
\hline Housewife & 127 & 62.0 \\
\hline Employed & 78 & 38.0 \\
\hline \multicolumn{3}{|c|}{ Husband educational level } \\
\hline Basic and less & 36 & 17.6 \\
\hline Secondary & 113 & 55.1 \\
\hline University & 56 & 27.3 \\
\hline \multicolumn{3}{|l|}{ Husband occupation } \\
\hline Employee & 65 & 31.7 \\
\hline Full-time job & 138 & 67.3 \\
\hline Unemployed & 2 & 1.0 \\
\hline \multicolumn{3}{|l|}{ Kind of house } \\
\hline Personal & 137 & 66.8 \\
\hline Rental & 34 & 16.6 \\
\hline Living with relatives & 34 & 16.6 \\
\hline \multicolumn{3}{|l|}{ Residence } \\
\hline Rural & 140 & 68.3 \\
\hline Urban & 65 & 31.7 \\
\hline \multicolumn{3}{|c|}{ Family income adequacy for living } \\
\hline Adequate & 131 & 63.9 \\
\hline In adequate & 29 & 14.1 \\
\hline Saving & 45 & 22.0 \\
\hline
\end{tabular}

Table 3 describes frequency distribution of reasons for preferring vaginal delivery or elective cesarean section among pregnant women. Regards the most highly observed reasons for preferring vaginal delivery were quicker post-delivery recovery and natural way of delivery by $66.36 \%$ and $37.38 \%$ respectively compared to the most highly observed reasons for preferring elective CS were fear of vaginal birth and CS is safer for baby by $56.12 \%$ and $26.53 \%$ respectively.

Table 4 illustrates frequency distribution of associated factors of childbirth fear among pregnant women. The first factor consisted of eight statements, the highest score those women agree were obtained for the subsequent statements: "I'm afraid of pain in childbirth" (89.3\%) "I'm afraid of episiotomy" (83.9\%) "I'm afraid of lacerations" (82.4\%). Five statements loaded on the second factor; the highest three statements that women agree were "I'm afraid that my child will get injured during childbirth" (75.6\%) "I'm afraid that I'll give birth to a dead child" (73.2\%) "I'm afraid that my child will be sick or handicapped" (70.7\%). Four statements loaded on the third factor, the highest score statement that women agree was 'I'm afraid of being left alone during childbirth" $(62.9 \%)$. The fourth factor consisted of three statements; the highest score statement that women agree was 'I' $m$ afraid that there will be problems with child's care and rearing" $(50.2 \%)$. The last factor consisted of only one statement, related to fears of having to undergo a cesarean section $(80.0 \%)$.

Table 5 shows average score of factors of fear of childbirth among pregnant women. The results revealed that childbirth factor was the highest factor associated with childbirth fear with mean \pm SD $12.439 \pm 3.949$ and cesarean section factor was the lowest factor associated with childbirth fear with mean $\pm \mathrm{SD} 1.390 \pm 0.882$. The mean of total factors of childbirth fear was $36.883 \pm 10.116$.

Table 2. Frequency distribution of obstetrical history among pregnant women

\begin{tabular}{|c|c|c|}
\hline Obstetrical History & No. $(n=205)$ & $\%$ \\
\hline \multicolumn{3}{|c|}{ Antenatal class attendance } \\
\hline Yes & 31 & 15.1 \\
\hline No & 174 & 84.9 \\
\hline \multicolumn{3}{|l|}{ Number of gravida } \\
\hline 1 & 156 & 76.1 \\
\hline 2 & 43 & 21.0 \\
\hline $3-5$ & 6 & 2.9 \\
\hline \multicolumn{3}{|c|}{ Number of miscarriages } \\
\hline None & 156 & 76.1 \\
\hline 1 & 43 & 21.0 \\
\hline $2-5$ & 6 & 2.9 \\
\hline \multicolumn{3}{|c|}{ Gestational age (weeks) } \\
\hline 30-34/wks. & 115 & 56.1 \\
\hline $35-40 /$ wks. & 90 & 43.9 \\
\hline \multicolumn{3}{|c|}{$\begin{array}{l}\text { History of cesarean delivery } \\
\text { among relatives }\end{array}$} \\
\hline Yes & 138 & 67.3 \\
\hline No & 67 & 32.7 \\
\hline \multicolumn{3}{|c|}{$\begin{array}{l}\text { Number of relatives who } \\
\text { have had cesarean delivery }\end{array}$} \\
\hline $1-2$ & 93 & 67.4 \\
\hline $3-4$ & 40 & 29.0 \\
\hline$\geq 5$ & 5 & 3.6 \\
\hline
\end{tabular}

Figure 1. Frequency distribution of delivery mode preference among pregnant women 
Table 3. Frequency distribution of reasons for preferring vaginal delivery or elective cesarean section among pregnant women

\begin{tabular}{lll}
\hline Items & No. $(\mathbf{n}=\mathbf{2 0 5})$ & \% \\
\hline Reasons for preferring vaginal delivery & & \\
Quicker post-delivery recovery & 71 & 66.36 \\
Natural way of delivery & 40 & 37.38 \\
Experience of vaginal delivery for the mother & 18 & 16.82 \\
Less overall pain & 15 & 14.02 \\
Safer for the baby & 21 & 19.63 \\
Safer for the mother & 25 & 23.36 \\
Doctor's advice & 8 & 7.48 \\
Other reasons (less complications) & 4 & 3.74 \\
Reasons for preferring elective cesarean section & & \\
Fear of vaginal birth & 55 & 56.12 \\
Safer for baby & 26 & 26.53 \\
Less overall pain & 20 & 20.40 \\
No influence on postpartum sexual life & 23 & 23.50 \\
Allows better control of time of birth & 21 & 21.43 \\
Less vaginal trauma & 18 & 18.37 \\
Convenience for sterilization & 14 & 14.28 \\
Doctor's advice & 20 & 20.40 \\
Other reasons (husband choice) & 9 & 9.18 \\
\hline
\end{tabular}

Table 4. Frequency distribution of associated factors of childbirth fear among pregnant women

\begin{tabular}{|c|c|c|c|c|c|c|c|c|}
\hline \multirow[t]{2}{*}{ Factors and items } & \multicolumn{2}{|c|}{ Agree } & \multicolumn{2}{|c|}{$\begin{array}{l}\text { Agree to some } \\
\text { extent }\end{array}$} & \multicolumn{2}{|c|}{$\begin{array}{l}\text { Disagree to } \\
\text { some extent }\end{array}$} & \multicolumn{2}{|c|}{ Do not agree } \\
\hline & No. & $\%$ & No. & $\%$ & No. & $\%$ & No. & $\%$ \\
\hline \multicolumn{9}{|l|}{ Factor 1. Childbirth } \\
\hline Pain (uterine contractions) & 183 & 89.3 & 14 & 6.8 & 2 & 1.0 & 6 & 2.9 \\
\hline Prolonged childbirth & 127 & 62.0 & 46 & 22.4 & 8 & 3.9 & 24 & 11.7 \\
\hline Panic during childbirth & 114 & 55.6 & 43 & 21.0 & 28 & 13.6 & 20 & 9.8 \\
\hline Incompetent parturient & 117 & 57.1 & 54 & 26.3 & 17 & 8.3 & 17 & 8.3 \\
\hline Ruptures(lacerations) & 169 & 82.4 & 26 & 12.7 & 4 & 2.0 & 6 & 2.9 \\
\hline Episiotomy & 172 & 83.9 & 21 & 10.2 & 4 & 2.0 & 8 & 3.9 \\
\hline Unable to breathe and push correctly & 128 & 62.4 & 61 & 29.8 & 8 & 3.9 & 8 & 3.9 \\
\hline Not leaving hospital at right time & 93 & 45.4 & 36 & 17.6 & 28 & 13.6 & 48 & 23.4 \\
\hline \multicolumn{9}{|l|}{ Factor 2. Child's and Mother's Well-Being } \\
\hline Delivering a dead child & 150 & 73.2 & 37 & 18.0 & 5 & 2.4 & 13 & 6.4 \\
\hline Child being injured during childbirth & 155 & 75.6 & 35 & 17.1 & 5 & 2.4 & 10 & 4.9 \\
\hline Sick or handicapped child & 145 & 70.7 & 32 & 15.6 & 8 & 3.9 & 20 & 9.8 \\
\hline Problems during current pregnancy & 116 & 56.6 & 52 & 25.4 & 24 & 11.7 & 13 & 6.3 \\
\hline Problems during or after childbirth & 118 & 57.6 & 55 & 26.8 & 19 & 9.3 & 13 & 6.3 \\
\hline \multicolumn{9}{|l|}{ Factor 3. Health Care Staff } \\
\hline Unfriendly staff & 78 & 38.0 & 52 & 25.4 & 29 & 14.2 & 46 & 22.4 \\
\hline Not participate in decision making about childbirth & 76 & 37.1 & 47 & 22.9 & 31 & 15.1 & 51 & 24.9 \\
\hline Left alone during childbirth & 129 & 62.9 & 54 & 26.4 & 7 & 3.4 & 15 & 7.3 \\
\hline Asking silly questions & 68 & 33.2 & 51 & 24.9 & 18 & 8.8 & 68 & 33.1 \\
\hline \multicolumn{9}{|l|}{ Factor 4. Family Life } \\
\hline Problems in relationship with partner & 72 & 35.1 & 39 & 19.0 & 27 & 13.1 & 67 & 33.7 \\
\hline Sexual problems & 64 & 31.2 & 40 & 19.5 & 24 & 11.7 & 77 & 37.6 \\
\hline Problems with child's care and rearing & 103 & 50.2 & 32 & 15.6 & 16 & 7.8 & 54 & 26.4 \\
\hline \multicolumn{9}{|l|}{ Factor 5. Cesarean Section } \\
\hline Having to undergo cesarean section & 164 & 80.0 & 18 & 8.8 & 7 & 3.4 & 16 & 7.8 \\
\hline
\end{tabular}


Table 5. Average score of factors of fear of childbirth among pregnant women

\begin{tabular}{lllll}
\hline \multirow{2}{*}{ Items } & \multicolumn{3}{c}{ Score } \\
\cline { 2 - 5 } & Minimum & Maximum & Mean & \pm SD \\
\hline Factor 1. Childbirth & 8.00 & 32.00 & 12.439 & \pm 3.949 \\
Factor 2. Child's and Mother's Well-Being & 5.00 & 20.00 & 7.644 & \pm 3.441 \\
Factor 3. Health Care Staff & 4.00 & 16.00 & 8.473 & \pm 3.569 \\
Factor 4. Family Life & 3.00 & 12.00 & 7.098 & \pm 3.201 \\
Factor 5. Cesarean Section & 1.00 & 4.00 & 1.390 & \pm 0.882 \\
Total score & $\mathbf{2 1 . 0 0}$ & $\mathbf{8 4 . 0 0}$ & $\mathbf{3 6 . 8 8 3}$ & $\pm \mathbf{1 0 . 1 1 6}$ \\
\hline
\end{tabular}

Table 6 describes average score of causes of fear of childbirth among pregnant women. The results revealed that negative mood was the highest cause associated with childbirth fear with mean \pm SD $13.302 \pm 3.500$ and alarming information was the lowest cause associated with childbirth fear with mean \pm SD $5.961 \pm 2.067$. The mean of total causes of childbirth fear was $41.254 \pm 8.218$.

Table 7 describes frequency distribution of level of fear of childbirth among pregnant women. The six highest fear lev- els were "I am really afraid of giving birth" (50.7\%) "I have fear of something being wrong with the baby" $(56.6 \%)$ "I have fear of having to have a cesarean section" (53.7\%) "I have fear of vaginal tear when giving birth"(59.0\%) "I have fear of the baby being injured during the delivery" (63.4\%) "I have fear of painful labor contractions" (55.1\%). The least fear levels that pregnant women reported were having nightmares about the childbirth (9.3\%) and having difficulty relaxing when thinking of the coming birth (18.1\%).

Table 6. Average score of causes of fear of childbirth among pregnant women

\begin{tabular}{lllll}
\hline \multirow{2}{*}{ Items } & \multicolumn{3}{c}{ Score } \\
\cline { 2 - 5 } & Minimum & Maximum & Mean & \pm SD \\
\hline Cause 1. Negative Mood & 5.00 & 20.00 & 13.302 & \pm 3.500 \\
Cause 2. Negative Stories & 4.00 & 16.00 & 9.342 & \pm 3.441 \\
Cause 3. Alarming Information & 2.00 & 8.00 & 5.961 & \pm 2.067 \\
Cause 4. Disease & 2.00 & 8.00 & 6.517 & \pm 1.942 \\
Cause 5. Child-Related Problems & 2.00 & 8.00 & 6.132 & \pm 2.076 \\
Total score & $\mathbf{1 5 . 0 0}$ & $\mathbf{6 0 . 0 0}$ & $\mathbf{4 1 . 2 5 4}$ & $\mathbf{\pm 8 . 2 1 8}$ \\
\hline
\end{tabular}

Table 7. Frequency distribution of level of fear of childbirth among pregnant women

\begin{tabular}{|c|c|c|c|c|c|c|c|c|}
\hline \multirow{2}{*}{ Items } & \multicolumn{2}{|c|}{ No fear } & \multicolumn{2}{|c|}{ Low fear } & \multicolumn{2}{|c|}{ Moderate fear } & \multicolumn{2}{|c|}{ High fear } \\
\hline & No. & $\%$ & No. & $\%$ & No. & $\%$ & No. & $\%$ \\
\hline Losing control at the delivery & 20 & 9.8 & 55 & 26.8 & 68 & 33.2 & 62 & 30.2 \\
\hline Afraid of giving birth & 7 & 3.4 & 29 & 14.2 & 65 & 31.7 & 104 & 50.7 \\
\hline Have nightmares about the delivery & 132 & 64.4 & 35 & 17.0 & 19 & 9.3 & 19 & 9.3 \\
\hline Bleeding too much during delivery & 31 & 15.1 & 32 & 15.6 & 64 & 31.2 & 78 & 38.1 \\
\hline Being not able to help during delivery & 6 & 2.9 & 54 & 26.3 & 51 & 24.9 & 94 & 45.9 \\
\hline Something being wrong with baby & 10 & 4.9 & 33 & 16.1 & 46 & 22.4 & 116 & 56.6 \\
\hline Painful injections & 44 & 21.5 & 41 & 20.0 & 57 & 27.8 & 63 & 30.7 \\
\hline Being left alone during labor & 21 & 10.2 & 50 & 24.4 & 73 & 35.6 & 61 & 29.8 \\
\hline Having to have a cesarean section & 23 & 11.2 & 17 & 8.3 & 55 & 26.8 & 110 & 53.7 \\
\hline Vaginal tear when giving birth & 5 & 2.4 & 20 & 9.8 & 59 & 28.8 & 121 & 59.0 \\
\hline Baby being injured during delivery & 3 & 1.5 & 21 & 10.2 & 51 & 24.9 & 130 & 63.4 \\
\hline Painful labor contractions & 5 & 2.4 & 18 & 8.8 & 69 & 33.7 & 113 & 55.1 \\
\hline $\begin{array}{l}\text { Have difficulty relaxing when thinking of the } \\
\text { coming birth }\end{array}$ & 49 & 23.9 & 49 & 23.9 & 70 & 34.1 & 37 & 18.1 \\
\hline Fear of hospital environment & 37 & 18.1 & 43 & 21.0 & 78 & 38.0 & 47 & 22.9 \\
\hline Not getting the kind of care that women want & 18 & 8.8 & 51 & 24.9 & 79 & 38.5 & 57 & 27.8 \\
\hline Rating fear about childbirth as & 2 & 1.0 & 19 & 9.3 & 88 & 42.9 & 96 & 46.8 \\
\hline
\end{tabular}


Figure 2 illustrates frequency distribution of level of childbirth fear among pregnant women. The results revealed that $49.3 \%$ of pregnant women had high fear meanwhile $47.3 \%$ of pregnant women had moderate fear.

Figure 3 illustrates the association between level of childbirth fear and delivery mode preference. Data revealed that $47.7 \%$ of pregnant women who had moderate childbirth fear preferred vaginal delivery meanwhile $50.0 \%$ of pregnant women with high childbirth fear preferred cesarean section. There was no statistical significant relation between level of fear and delivery mode preference $(p=.954)$.

\section{Level of Childbirth Fear}

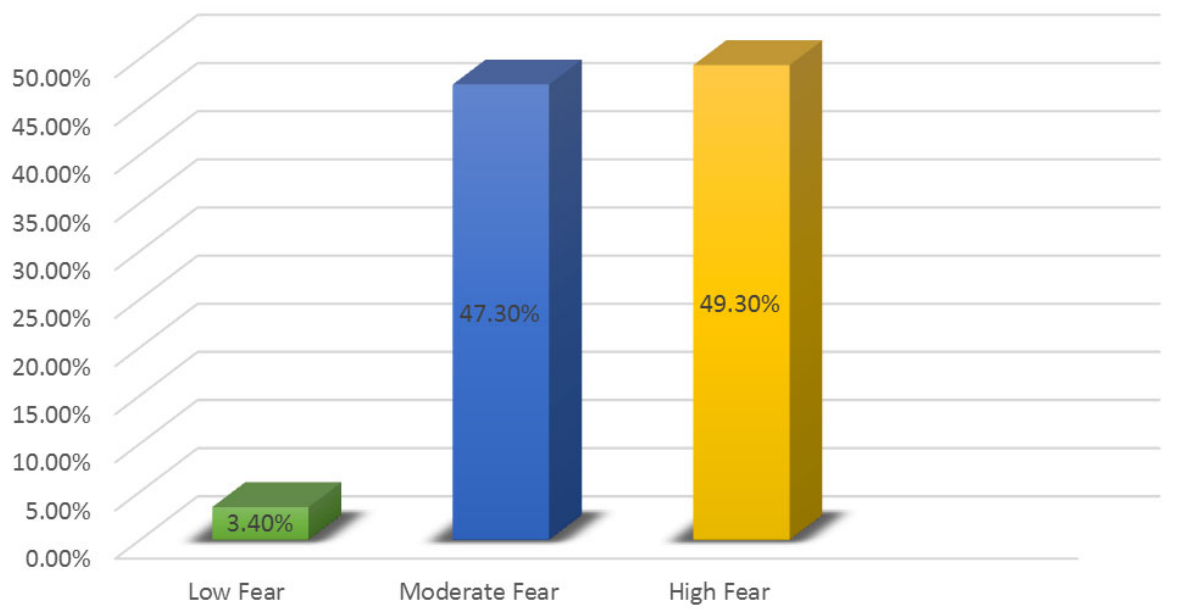

Figure 2. Frequency distribution of level of fear of childbirth among pregnant women

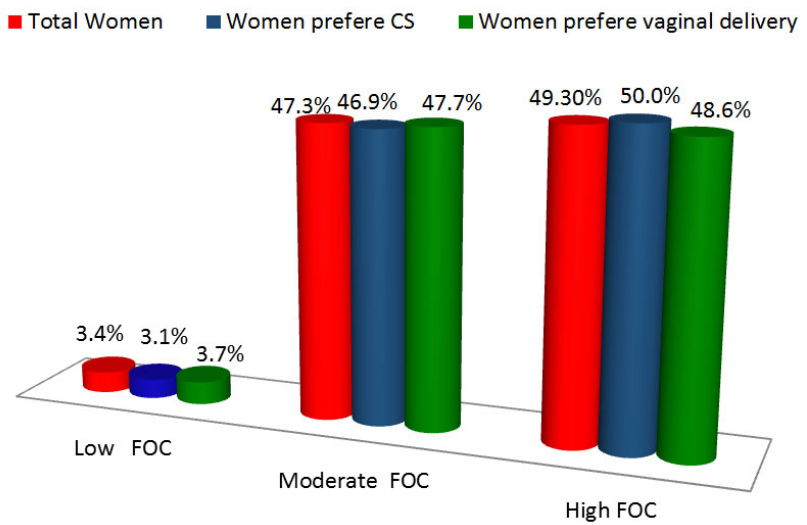

Figure 3. The association between level of childbirth fear and delivery mode preference

\section{Discussion}

The current study was a cross sectional descriptive study, which aimed to investigate factors associated with FOC and its effect on women's preference for elective cesarean section. The results of this study answered the study questions and revealed that childbirth factor was the highest factor associated with FOC. Fear of pain, episiotomy and lacerations were the highest sub factors representative for childbirth factor associated with FOC. Fear of vaginal birth, safer mode for the baby, no influence on postpartum sexual life and pain associated with delivery were the most reasons for CS preference. As well as such study findings revealed that pregnant women with high FOC preferred CS. Meanwhile there was no statistical significant relation between level of fear and delivery mode preference.

As regard general characteristics of pregnant women, the current study revealed that the mean age of pregnant women was $23.2 \pm 3.5$; about two thirds of them aged between 1823 years, more than half of them had secondary education, about two thirds of them were housewives, more than two thirds of them came from rural origin and about two thirds of them reported adequate income. These study findings were in agreement with Kizılirmak et al. ${ }^{[34]}$ who stated in their study conducted in Turkey regarding effect of education on childbirth fear that the mean age of pregnant women was $22.2 \pm 3.9,84 \%$ of them were not working, and $64 \%$ of them reported moderate income, meanwhile $28 \%$ of pregnant women came from village.

In addition, with Fouad et al. ${ }^{[35]}$ who study preference after VBAC and cesarean delivery after vaginal delivery in Egypt and reported that $73.3 \%$ of pregnant women were housewives, $66.7 \%$ of them came from rural origin and $60 \%$ reported enough income among cesarean delivery after vaginal delivery group. Moreover the results were in agreement with Elfeshawy et al. ${ }^{[36]}$ study conducted in Egypt regard- 
ing labor companionship who revealed that the mean age of pregnant women was $23.5 \pm 4.1,88 \%$ of pregnant women were housewives, $66 \%$ of them came from rural origin and $80 \%$ reported enough income.

In contrast, Toohill et al. ${ }^{[37]}$ who study childbirth fear in Australia and reported that the mean age of pregnant women was $28.8 \pm 5.2$, another study conducted in Norway by Adams et al. ${ }^{[38]}$ to assess childbirth fear who stated that the mean maternal age at delivery was $30.9 \pm 4.7$, also Haines et al. ${ }^{\text {[39] }}$ who study impact of fear on mode of delivery in Sweden and Australia stated that $69.9 \%$ of pregnant women were aged between $25-35$ years, $53.7 \%$ of pregnant women were college graduated.

Also the present study result was incongruent with Fouad et al. ${ }^{[35]}$ who stated that $73.3 \%$ of pregnant women were Primary/Preparatory school. Meanwhile study conducted in Norway by Fuglenes et al. ${ }^{[13]}$ to investigate cesarean section preference who found that $85.6 \%$ of pregnant women were working, and Mancuso et al. ${ }^{[40]}$ who study delivery mode preference in Southern Italy and reported that $62.3 \%$ of pregnant women were employed.

Concerning obstetrical history among pregnant women, the present study revealed that more than three quarters of pregnant women did not attend antenatal classes; about one quarter of them had miscarriage, and about half of women were pregnant between 35-40 weeks. This study finding was supported by Melender ${ }^{[32]}$ who stated in her study conducted in Western Finland to investigate fear of childbirth that $26.4 \%$ of pregnant women had abortion. Also, El-Nemer ${ }^{[41]}$ who reported in her study conducted in Egypt to investigate effect of childbirth education on cesarean delivery request that $17.5 \%$ of pregnant women in her study had abortion.

The present study findings were in disagreement with Melen$\operatorname{der}^{[32]}$ who reported that $49.0 \%$ of pregnant women attended antenatal classes. In addition, Chu et al. ${ }^{[42]}$ study conducted in Taiwan regarding cesarean delivery preference who found that $86.5 \%$ of women were pregnant between $37-40$ weeks.

As regard delivery mode preference, the present study findings revealed that around half of pregnant women preferred vaginal delivery and the other half preferred cesarean delivery. These study finding may be explained by that some women see vaginal delivery as natural method of childbirth and quicker post-delivery recovery when compared to CS, but some women may prefer cesarean section due to fear of labor pain and it has no influence on postpartum sexual life.

This study finding was in agreement with Mohammad et $a l .{ }^{[43]}$ who stated in their study conducted in South of Iran regarding cesarean delivery that $50.7 \%$ of nulliparous women preferred cesarean section. In contrast, Gholami and Salari$1 \mathrm{ak}^{[44]}$ who reported in their study conducted in Northeast of Iran regarding cesarean delivery preference that $18.6 \%$ of nulliparous women preferred cesarean section, and the same rate was detected by Yilmaz et al. ${ }^{[45]}$ who reported that $18.5 \%$ of women preferred elective cesarean section.

In the current study, regarding reasons for preferring cesarean delivery, the result findings revealed that more than half of pregnant women had fear of vaginal birth followed by worrying about baby safety which reported by more than one quarter of them. Such findings are supported by Faisal et $a l .{ }^{[46]}$ who conducted qualitative study in Iran about factors of cesarean section preference and revealed that fear of labor pain was the primary reason for requesting cesarean section followed by safety of the mother and infant.

Also, another study carried out in Turkey about CS preference and influencing factors by Buyukbayrak et al. ${ }^{[4]}$ who revealed that most of women preferred CS due to fear of vaginal delivery and a fifth of them preferred cesarean section due to their worries about their health, also they saw it as safer mode for their babies. In addition, El-Nemer ${ }^{[41]}$ who reported that the causes of requesting cesarean delivery were fear of normal labour and delivery, safety, less physical damage and less risk for mother and the baby.

Meanwhile, regarding reasons for preferring vaginal delivery, the study findings stated that about two thirds of women preferred vaginal delivery due to quicker post-delivery recovery, followed by about one third of them preferred it as they consider vaginal delivery as natural way of delivery. These findings can be interpreted by that study participants were from rural areas (more than two-thirds of them) and more than half of them have secondary education as they view vaginal delivery as natural, they fear from obstetric risks of CS, e.g., pain of wound and risk of anesthesia and they preferred to come back quickly to family's responsibilities as cesarean delivery causes a delay in both mothers' recovery and mother-baby interaction.

Such agreement between the study findings and Pang et $a l .{ }^{[48]}$ study which conducted in Hong Kong about impact of first childbirth on delivery mode preference who stated that women were detected to prefer vaginal delivery because of quick postpartum recovery which represented by $27.5 \%$ and being natural which represented by $24 \%$ of them.

Also Yilmaz et al. ${ }^{[45]}$ who conducted study regarding delivery mode preference in Iran stated that women preferring vaginal delivery were associated with some reasons such as vaginal delivery was a healthier, more natural way of delivery, more comfortable postpartum period and quick postpartum 
recovery which represented by $89.2 \%, 75.5 \%, 82.3 \%, 88.6 \%$ respectively compared to cesarean section. In addition, in study conducted in Egypt by Mohamed et al. ${ }^{[49]}$ compared two groups of pregnant women, regarding their preference for $\mathrm{C}$-section or vaginal delivery and reported that the most significant reasons for preferring vaginal delivery were that it was considered a natural way of delivery, followed by shorter postpartum healing process.

Considering the items of factors of childbirth fear, the present study showed that the most represented factor associated with fear of childbirth of pregnant women was childbirth factor. This result may be due to that all study participants were nulliparous women which considered the first experience for them with labor as they afraid of labor pain, laceration and episiotomy. Increasing maternal awareness about pain-relief methods during labor in hospitals will consequently reduce maternal fear of pain and encourage mothers to prefer vaginal delivery. This finding was in agreement with Melender ${ }^{[32]}$ who found that childbirth factor had the strongest relative explanatory power.

The primary source of fear in this study was negative mood followed by negative stories that they had heard about baby care, pregnancy and childbirth. These finding can be interpreted by that study participants were nulliparous women and did not experience childbirth before but heard frightening stories about childbirth and baby care from their relatives and friends.

Findings were in consistent with Melender ${ }^{[32]}$ who revealed that negative mood had the strongest relative explanatory power and negative stories had a strong explanatory power. In contrary with the present study finding, Serçekuş and Okumuş ${ }^{[28]}$ who study childbirth fear in Turkey and revealed that negative stories that women had heard about childbirth or health-care personnel was the primary source of fear.

Considering the level of fear of childbirth among pregnant women, the present study revealed that childbirth fear among nulliparous women is associated with fear of pain, fear of vaginal tear, the well-being of the baby, or requiring an emergency caesarean section. Fear of labor pain and lack of childbirth education characterize Egyptian women's experience of pregnancy and childbirth. Ternström et al. ${ }^{[50]}$ supported the present study findings in their cross-sectional study that was conducted to explore the prevalence of FOC in Sweden, they concluded that childbirth related factors among primiparous women is based on fear of pain, the well-being of the baby, being physically damaged or loss of control.

Also in study conducted by Serçekuş and Okumuş ${ }^{[28]}$ who stated that fear of pain, fear of dying and complications such as haemorrhage or requiring an emergency CS described by study participants, but concerns for the baby was a less common finding in that study. Additionally, other studies have supported that the women were afraid of pain, inadequate support, losing control and any harmful effects labor may have on their body. ${ }^{[39,51-53]}$

Regarding prevalence of fear among pregnant women, the present study indicated that about half of pregnant women had high fear. The factors for higher levels of fear and higher prevalence in nulliparous women might be associated with the uncertainty of delivery, or because these women are dealing with a great life transition (physically, psychologically and socially) to be a mother.

Salomonsson ${ }^{[54]}$ was in agreement with this study finding as she reported in her study conducted in Sweden to investigate childbirth fear in nulliparous pregnant women that $21 \%$ of the pregnant women fulfilled the criterion for high fear of childbirth. In comparison, in a large Swedish sample, Ryding et al. ${ }^{[55]}$ study conducted to investigate childbirth fear who found that $10 \%$ of women had severe fear of childbirth.

In the current study, the total mean of CAQ score of pregnant Egyptian women was 47.512. These results were compared with those from other countries. Lowe ${ }^{[33]}$ who assess selfefficacy for fear of childbirth in USA reported that the total CAQ score of pregnant American women was 31.17, also Gao et al. ${ }^{[56]}$ study carried out in China to analyze cesarean section indications stated that the total CAQ score of pregnant Chinese women was 31.2 which was almost the same as that of pregnant American women. It showed that the pregnant Egyptian women might have higher fear of childbirth than the pregnant American and Chinese women had.

The difference in CAQ mean score may be associated with the lower level of education in pregnant Egyptian women in this study as more than half of pregnant women had secondary education, where as in Chinese study $65.4 \%$ of pregnant women were college or above graduates. This finding was in agreement with previous study conducted in Denmark to investigate childbirth fear in nulliparous women revealed that a lower education level was significant trait related to fear of childbirth. ${ }^{[57]}$

Regarding the association between level of fear and delivery mode preference. Data revealed that preference for CS was not significantly associated with high fear of childbirth however it was more common in pregnant women with high fear (half of women). Consistent with the current study findings, Karlström et al. ${ }^{[58]}$ study conducted in a Mid Sweden county to investigate childbirth fear in women preferred cesarean and vaginal delivery who concluded that women who pre- 
ferred and actually were delivered by CS experienced FOC to a higher level compared to women with a vaginal delivery. In the contrary, Nieminen et al. ${ }^{[17]}$ who found that a significant relation between childbirth fear and women's preference for CS. Childbirth fear in several studies reported as an effective cause in women's preference for cesarean delivery. ${ }^{[13,18]}$

\section{Conclusion}

Overall the findings of the current study highlighted that, nearly half of pregnant women $(47.8 \%)$ preferred elective CS. Women who preferred elective CS are concerned with fear of vaginal birth, safety of the baby, no influence on postpartum sexual life, and pain associated with delivery. Childbirth factor was the highest factor associated with childbirth fear. Fear of pain, episiotomy and lacerations were the highest sub factors representative for childbirth factor. Preference for a CS was associated with high FOC. Pregnant women with high childbirth fear preferred cesarean section. Though, there was no statistical significant relation between level of fear and delivery mode preference.

\section{Recommendations}

Based on the current study findings, the following is recommended:

Undertaking information, education and communication programs to increase awareness of the women, husbands, health providers and society about childbirth fear and its effect on cesarean section preference in order to decrease elective cesarean section rate, this can be done through:

- Childbirth education courses suited and tailored to the culture of the Egyptian women in the second or third trimester of pregnancy for preparing women to suppose an active role in childbirth.

- Providing opportunities for women who have fear of childbirth to communicate with women who had favorable birth experiences for reducing fear.

- Healthcare professionals should certainly instruct and provide information to women and their partners over health benefits of vaginal delivery and reassure them in their ability to give birth and become a mother while providing antenatal care.

- Including antenatal educational program into maternity nursing undergraduate curriculum.

- Further researches are needed especially to compare the levels of fear among nulliparous women and women with more than one delivery.

\section{ACKNOWLEDGEMENTS}

Researchers offer grateful thanks to all participants for their cooperation during the research process and all appreciation to the health team for their invaluable assistance during data collection.

\section{CONFlicts of InTEREST Disclosure}

The authors declare that there is no conflict of interest.

\section{REFERENCES}

[1] Farahat ZAM. Women's Expectations And Experiences Of Childbirth In An Egyptian Public Hospital (Doctoral dissertation, The American University in Cairo). 2010.

[2] Kabakian-Khasholian T, El-Nemer A, Bashour H. Perceptions about labor companionship at public teaching hospitals in three Arab countries. International Journal of Gynecology and Obstetrics. 2015; 129(2015): 223-226. PMid:25770351 http://dx.doi.org/10.10 16/j.ijgo.2014.12.005

[3] Wiklund I, Edman G, Ryding EL, et al. Expectation and experiences of childbirth in primiparae with caesarean section. BJOG: An International Journal of Obstetrics \& Gynaecology. 2008; 115(3): 324-331. PMid:18190368 http://dx.doi.org/10.1111/j.147 $1-0528.2007 .01564 . x$

[4] Eriksson C, Jansson L, Hamberg K. Women's experiences of intense fear related to childbirth investigated in a Swedish qualitative study. Midwifery. 2006; 22(3): 240-248. PMid:16603282 http://dx.doi.org/10.1016/j.midw.2005.10.002

[5] Rouhe H, Salmela-Aro K, Halmesmäki E, et al. Fear of childbirth according to parity, gestational age, and obstetric history. BJOG: An International Journal of Obstetrics \& Gynaecology. 2009;
116(1): 67-73. PMid:19055652 http://dx.doi.org/10.1111/j $.1471-0528.2008 .02002 . x$

[6] Rouhe H, Salmela-Aro K, Gissler M, et al. Mental health problems common in women with fear of childbirth. BJOG: An International Journal of Obstetrics \& Gynaecology. 2011; 118(9): 11041111. PMid:21489127 http://dx.doi .org/10.1111/j.1471-0 $528.2011 .02967 . x$

[7] Zeldes K, Norsigian J. Encouraging Women to Consider a Less Medicalized Approach to Childbirth Without Turning Them Off: Challenges to Producing Our Bodies, Ourselves: Pregnancy and Birth Birth. 2008; 35(3): 245-249. PMid:18844651 http://dx.doi.org /10.1111/j.1523-536X.2008.00246.x

[8] Karlström A, Engström-Olofsson R, Nystedt A, et al. Swedish caregivers' attitudes towards caesarean section on maternal request. Women and Birth. 2009; 22(2): 57-63. PMid:19195958 http://dx.doi.org/10.1016/j.wombi.2008.12.002

[9] Karlström A, Rådestad I, Eriksson C, et al. Cesarean Section without Medical Reason, 1997 to 2006: A Swedish Register Study. Birth 2010; 37(1): 11-20. PMid:20402717 http://dx.doi .org/10.11 $11 / \mathrm{j} \cdot 1523-536 \mathrm{X} \cdot 2009.00373 . \mathrm{x}$

[10] Roduit C, Scholtens S, de Jongste JC, et al. Asthma at 8 years of age in children born by caesarean section. Thorax. 2009; 64(2): 107- 
113. PMid:19052046 http://dx.doi .org/10.1136/thx. 2008. 100875

[11] Schlinzig T, Johansson S, Gunnar A, et al. Epigenetic modulation at birth - altered DNA-methylation in white blood cells after Caesarean section. Acta Paediatrica. 2009; 98(7): 1096-1099. PMid:19638013 http://dx.doi.org/10.1111/j.1651-2227.2009.01371.x

[12] Naeem M, Muhammad Khan Z, Abbas S, et al. Rate and Indication of elective and emergency cesarean section: a study in a tertiary care hospital of peshawar. J Ayub Med Coll Abbottabad. 2015; 27(1): 151-4. PMid:26182763

[13] Fuglenes D, Aas E, Botten G, et al. Why do some pregnant women prefer cesarean? The influence of parity, delivery experiences, and fear. American Journal of Obstetrics and Gynecology. 2011; 205(1): 45.e1-45.e9. PMid:21620366 http://dx.doi.org/10.1016/j.a jog. 2011.03 .043

[14] Betrán AP, Merialdi M, Lauer JA, et al. Rates of caesarean section: analysis of global, regional and national estimates. Paediatric and Perinatal Epidemiology. 2007; 21(2): 98-113. PMid:17302638 http://dx.doi.org/10.1111/j.1365-3016.2007.00786.x

[15] Karlström A, Lindgren H, Hildingsson I. Maternal and infant outcome after caesarean section without recorded medical indication: findings from a Swedish case-control study. BJOG: An International Journal of Obstetrics \& Gynaecology. 2013; 120(4): 479-486. PMid:23316937 http://dx.doi.org/10.1111/1471-0528.12 129

[16] Klossner N, Hatfield N. Introductory maternity and pediatric nursing, 2nd ed. China, Wolters kluwer Health, Lippincott Williams \& Wilkins Co. 2009; 202-235.

[17] Nieminen K, Stephansson O, Ryding EL. Women's fear of childbirth and preference for cesarean section - a cross-sectional study at various stages of pregnancy in Sweden. Acta Obstetricia et Gynecologica Scandinavica. 2009; 88(7): 807-813. PMid:19488882 http://dx.doi.org/10.1080/00016340902998436

[18] Fenwick J, Staff L, Gamble J, et al. Why do women request caesarean section in a normal, healthy first pregnancy? Midwifery. 2010; 26(4): 394-400. PMid:19117644 http://dx.doi.org/10.1016/j.mid w. 2008.10 .011

[19] Hamilton BE, Martin JA, Ventura SJ. Births: Preliminary Data for 2011. National Vital Statistics Reports. Volume 61, Number 5. Centers for Disease Control and Prevention. 2012.

[20] Gibbons L, Belizan JM, Lauer JA, et al. Inequities in the use of cesarean section deliveries in the world. American Journal of Obstetrics and Gynecology. 2012; 206(4): 331.e1-331.e19. PMid:22464076 http://dx.doi.org/10.1016/j.ajog.2012.02.026

[21] El-Zanaty F, Ann A. Egypt Demographic and Health Survey 2014. Calverton, Maryland: Ministry of Health and Population [Arab Republic of Egypt], El-Zanaty and Associates, and Macro International. 2015.

[22] Alehagen S, Wijma B, Wijma K. Fear of childbirth before, during and after childbirth. Acta Obstetricia et Gynecologica Scandinavica 2006; 85: 56-62. http://dx.doi.org/10.1080/00016340500 334844

[23] Eriksson C, Westman G, Hamberg K. Content of childbirth related fear in Swedish women and men- analysis of an open ended question. Journal of Midwifery \& Women's Health. 2006; 51 (2): 112118. PMid: 16504908 http://dx.doi.org/10.1016/j.jmwh. 20 05.08 .010

[24] Ayers S, Eagle A, Waring H. The effects of childbirth related posttraumatic stress disorder on women and their relationships: a qualitative study. Psychological Health and Medicine. 2006; 11: 389398. PMid:17129916 http://dx.doi .org/10.1080/135485006 00708409
[25] Fenwick J, Gamble J, Nathan E, et al. Pre- and postpartum levels of childbirth fear and the relationship to birth outcomes in a cohort of Australian women. Journal of Clinical Nursing. 2009; 18(5): 667677. PMid: 19239535 http://dx.doi.org/10.1111/j.1365-2 $702.2008 .02568 . x$

[26] Haines H, Pallant J, Karlström A, et al. Cross cultural comparison of levels of childbirth-related fear in an Australian and Swedish sample. Midwifery. 2011; 27: 560-567. PMid:20598787 http: //dx.doi.org/10.1016/j.midw.2010.05.004

[27] Hall W, Hauk Y, Carty E, et al. Childbirth fear, anxiety, fatigue, and sleep deprivation in pregnant women. Journal of Obstetric, Gynecologic, \& Neonatal Nursing. 2009; 38(5): 567-576. PMid:19883478 http://dx.doi.org/10.1111/j.1552-6909.2009.01054.x

[28] Serçekuş P, Okumuş H. Fears associated with childbirth among nulliparous women in Turkey. Midwifery. 2009; 25(2): 155162. PMid:17600599 http://dx.doi.org/10.1016/j.midw . 20 07.02 .005

[29] Kjærgaard H, Wijma K, Dykes AK, et al. Fear of childbirth in obstetrically low-risk nulliparous women in Sweden and Denmark. Journal of Reproductive and Infant Psychology. 2008; 26(4): 340-350. http://dx.doi.org/10.1080/02646830802408498

[30] Hofberg K, Ward M. Tokophobia Tokophobia: A Profound Dread and Avoidance of Childbirth (When Pathological Fear Effects the Consultation). In Psychological Challenges in Obstetrics and Gynecology, Springer, London. 2007. PMid:17725237 http://dx. doi . org/10.1007/978-1-84628-808-1_16

[31] Rahimparvar SF, Hamzehkhani M, Geranmayeh M, et al. Effect of educational software on self-efficacy of pregnant women to cope with labor: a randomized controlled trial. Archives of Gynecology and Obstetrics. 2012; 286(1): 63-70. PMid:22350327 http://dx.doi.org/10.1007/s00404-012-2243-4

[32] Melender RM. Experiences of Fears Associated with Pregnancy and Childbirth: A Study of 329 Pregnant Women. Birth. 2002; 29(2): 101-111. http://dx.doi.org/10.1046/j.1523-536X.2002.0 $0170 . x$

[33] Lowe NK. Self-efficacy for labor and childbirth fears in nulliparous pregnant women. Journal of Psychosomatic Obstetrics \& Gynecology. 2000; 21 (4) 219-224. PMid:11191169 http://dx . doi .org $/ 10.3109 / 01674820009085591$

[34] Kızılırmak A, Başer M. The effect of education given to primigravida women on fear of childbirth. Applied Nursing Research. 2016; 29 : 19-24. PMid:26856483 http://dx.doi.org/10.1016/j .apnr. 2015.04.002

[35] Fouad S, Fathy T, El-nemer A. Women's Satisfaction and Preferences Following Vaginal Birth After Caesarean Section and Caesarean Section after Vaginal Birth. Mansoura Nursing Journal. 2015; 2(2).

[36] Elfeshawy NIM, Elmashad HAM, El-Nemer AMR. Feasibility and Acceptability of Labor Companionship at Mansuora University Hospital/Egypt. ISOR Journal of Nursing and Health Science. 2015; 4(5).

[37] Toohill J, Fenwick J, Gamble J, et al. Prevalence of childbirth fear in an Australian sample of pregnant women. BMC Pregnancy Childbirth. 2014; 14(1): 275. PMid:25123448 http://dx.doi.org/10. 1186/1471-2393-14-275

[38] Adams S, Eberhard-Gran M, Eskild A. Fear of childbirth and duration of labour: a study of 2206 women with intended vaginal delivery. BJOG: An International Journal of Obstetrics \& Gynaecology. 2012; 119(10): 1238-1246. PMid:22734617 http://dx.doi.org/10.11 $11 / j .1471-0528.2012 .03433 . x$

[39] Haines H, Rubertsson C, Pallant JF, et al. Womens' attitudes and beliefs of childbirth and association with birth preference: A comparison of a Swedish and an Australian sample in mid-pregnancy. 
Midwifery. 2012; 28(6): e850-e856. PMid:22098781 http://dx.d oi.org/10.1016/j.midw.2011.09.011

[40] Mancuso A, De Vivo A, Fanara G, et al. Women's preference on mode of delivery in Southern Italy. Acta Obstetricia et Gynecologica Scandinavica. 2006; 85(6): 694-699. PMid:16752261 http://dx.doi.org/10.1080/00016340600645255

[41] El-Nemer A. Effect of Childbirth Counseling on Pregnant Women Requested for Cesarean Delivery. IOSR Journal of Nursing and Health Science (IOSR-JNHS). 2015; 4(4): 24:29.

[42] Chu KH, Tai CJ, Hsu CS, et al. Women's preference for cesarean delivery and differences between Taiwanese women undergoing different modes of delivery. BMC Health Services Research. 2010; 10(1): 138. PMid:20504354 http://dx.doi.org/10.1186/147 2-6963-10-138

[43] Mohammad BA, Tabatabaei S, Mohammad SN, et al. Factors influencing cesarean delivery method in Shiraz hospitals. Iran Journal of Nursing. 2009; 21(56): 37-45.

[44] Gholami A, Salarilak S. Why do some pregnant women prefer cesarean delivery in first pregnancy? Iranian Journal of Reproductive Medicine. 2013; 11(4): 301-308. PMid:24639760

[45] Yilmaz SD, Bal MD, Beji NK, et al. Women's Preferences of Method of Delivery and Influencing Factors. Iranian Red Crescent Medical Journal. 2013; 15(8): 683-689. PMid:24578835 http: //dx.doi.org/10.5812/ircmj.11532

[46] Faisal I, Matinnia N, Hejar A, et al. Why do primigravidae request caesarean section in a normal pregnancy? A qualitative study in Iran. Midwifery. 2014; 30(2): 227-233. PMid:24055288 http://dx.doi.org/10.1016/j.midw.2013.08.011

[47] Buyukbayrak E, Kaymaz O, Kars B, et al. Caesarean delivery or vaginal birth: Preference of Turkish pregnant women and influencing factors. Journal of Obstetrics and Gynaecology. 2010; 30(2): 155158. PMid:20143975 http://dx.doi.org/10.3109/014436109 03461436

[48] Pang MW, Leung TN, Lau TK, et al. Impact of First Childbirth on Changes in Women's Preference for Mode of Delivery: Follow-up of a Longitudinal Observational Study. Birth. 2008; 35(2): 121128. PMid: 18507583 http://dx.doi.org/10.1111/j.1523-5 36X.2008.00225. $\mathrm{x}$

[49] Mohamed SL, El Fouly H, Mohamed LM. Women's Preferences for Mode of Delivery in Upper and Lower Egypt: A Comparative Study. IOSR Journal of Nursing and Health Science (IOSR-JNHS). 2016; 5(3): $35-45$.
[50] Ternström E, Hildingsson I, Haines H, et al. Higher prevalence of childbirth related fear in foreign born pregnant women - Findings from a community sample in Sweden. Midwifery. 2015; 31(4): 445450. PMid:25529841 http://dx.doi.org/10.1016/j.midw. 20 14.11 .011

[51] Nilsson C, Lundgren I, Karlström A, et al. Self reported fear of childbirth and its association with women's birth experience and mode of delivery: A longitudinal population-based study. Women and Birth 2012; 25(3): 114-121. PMid:21764400 http://dx.doi.org/10. 1016/j.wombi.2011.06.001

[52] Haines HM, Rubertsson C, Pallant JF, et al. The influence of women's fear, attitudes and beliefs of childbirth on mode and experience of birth. BMC Pregnancy and Childbirth. 2012; 12(1): 1-14. PMid:22727217 http://dx.doi.org/10.1186/1471-239 3-12-55

[53] ChoobMasjedi SG, Hasani J, Khorsandi M, et al. Cognitive factors related to childbirth and their effect on women's delivery preference: a comparison between a private and public hospital in Tehran. Eastern Mediterranean Health Journal. 2012; 18(11).

[54] Salomonsson B. Fear is in the air: Midwives' perspectives of fear of childbirth and childbirth self-efficacy and fear of childbirth in nulliparous pregnant women, Linköping University Medical Dissertations, ISSN 0345-0082 ; 1334. Linköping University Electronic Press; 2012.

[55] Ryding EL, Wirfelt E, Wängborg IB, et al. Personality and fear of childbirth. Acta Obstetricia et Gynecologica Scandinavica. 2007; 86(7): 814-820. PMid:17611826 http://dx.doi.org/10.1080 100016340701415079

[56] Gao Y, Xue Q, Chen G, et al. An analysis of the indications for cesarean section in a teaching hospital in China. European Journal of Obstetrics \& Gynecology and Reproductive Biology. 2013; 170(2): 414-418. PMid:23978503 http://dx.doi.org/10.1016/j.ejo grb. 2013.08.009

[57] Laursen M, Hedegaard M, Johansen C. Fear of childbirth: predictors and temporal changes among nulliparous women in the Danish National Birth Cohort. BJOG: An International Journal of Obstetrics \& Gynaecology. 2008; 115(3): 354-360. PMid:18190372 http://dx.doi.org/10.1111/j.1471-0528.2007.01583.x

[58] Karlström A, Nystedt A, Johansson M, et al. Behind the myth-few women prefer caesarean section in the absence of medical or obstetrical factors. Midwifery. 2011; 27(5): 620-627. PMid:20630634 http://dx.doi.org/10.1016/j.midw.2010.05.005 